\author{
Jurnal Kumara Cendekia \\ https://jurnal.uns.ac.id/kumara
}

\title{
KEGIATAN COOKING CLASS SEBAGAI UPAYA PEMBIASAAN MENGONSUMSI MAKANAN SEHAT PADA ANAK USIA 4-5 TAHUN
}

\author{
Novita Maharani ${ }^{1}$, Siti Istiyati ${ }^{2}$, Warananingtyas Palupi ${ }^{1}$ \\ ${ }^{1}$ Program Studi PG-PAUD, Universitas Sebelas Maret Surakarta \\ ${ }^{2}$ Program Studi PGSD, Universitas Sebelas Maret Surakarta
}

Email : novitamaharani80@gmail.com, siti_ipgsd@yahoo.co.id, palupi@fkip.uns.ac.id

\begin{abstract}
ABSTRAK
Tujuan penelitian ini adalah menerapkan kegiatan cooking class sebagai upaya pembiasaan mengonsumsi makanan sehat pada kelompok A TK Gaya Baru III Surakarta. Jenis penelitian ini adalah penelitian tindakan kelas (PTK) dengan pendekatan kualitatif. Subjek dalam penelitian ini adalah anak usia 4-5 tahun dengan jumlah 16 anak pada kelompok A TK Gaya Baru III Surakarta tahun ajaran 2018/ 2019. Sumber data dalam penelitian ini adalah anak dan guru. Teknik pengumpulan data dalam penelitian ini menggunakan observasi, wawancara, dan dokumentasi. Teknik uji validitas data yang digunakan adalah triangulasi sumber dan triangulasi teknik. Hasil penelitian siklus I diperoleh sejumlah 7 anak sudah terbiasa mengonsumsi makanan sehat.Siklus II tingkat terbiasa mengonsumsi makanan sehat anak mencapai sebanyak 11 anak. Pada siklus III tingkat terbiasa mengonsumsi makanan sehat anak mencapai sebanyak 16 anak. Peningkatan tersebut ditandai dengan anak sudah terbiasa mengonsumsi daging dan sumber protein lainnya, mengonsumsi sayuran dan mengonsumsi buahbuahan. Berdasarkan uraian diatas, hasil penelitian tindakan kelas yang dilaksanakan dapat ditarik kesimpulan bahwa penerapan kegiatan cooking class dapat digunakan sebagai upaya untuk pembiasaan mengonsumsi makanan sehat pada anak.usia 4-5 tahun.
\end{abstract}

Kata kunci: Cooking class, pembiasaan mengonsumsi makanan sehat, anak usia dini

\section{ABSTRACT}

This study aimed to implement cooking class activities to habituate consuming healthy food in group A at TK Gaya Baru III Surakarta. This research applied classroom action research (CAR) with a qualitative approach. The subjects in this study were 4-5 years old children with a total of 16 children in group A at TK Gaya Baru III Surakarta in the academic year of 2018 / 2019. Sources of data in this study were children and teachers. Data collection techniques in this study used observation, interviews, and documentation. The data validity technique used was source triangulation and technical triangulation. The result of the first cycle of research obtained a number of 7 children are used to eatng healthy food. The second cycle of the level of accustomed eating healthy food for children reaches as many as 11 children. In the third cycle the level of accustomed to eating healthy food reached as many as 16 children. The increase was marked by children who were used to eating meat and other protein sources, eating vegetables and eating fruits. Based on the description above, the results of the classroom action research conducted can be concluded that the application of cooking class activities can be used as an effort to habituate to eating healthy foods in children aged 4-5 years.

Keywords: Cooking class, the habit of consuming healthy food, early childhood 


\section{PENDAHULUAN}

Anak Taman Kanak-Kanak (TK) memiliki ciri khas yaitu..sedang mengalami masa tumbuh kembang yangnncepatnnbaiknnnfisik,Nmental.. maupun intelektual.Tumbuh kembang anak usia prasekolah yang optimal dipengaruhi oleh jumlah makanan yang dikonsumsi dan kualitas pemberiannzat..gizinyangndiberikan.. dalam makanannya (Hardiansyah \& Supariasa, 2014).

Pola makan sehat ditetapkan oleh Kementerian Kesehatan dengan Keputusan No. 41 tahun 2014 untuk kelompok anak usia prasekolah sebagai berikut: 1) Membiasakan makan tiga kali sehari (pagi siang dan malam); 2) Mengonsumsi ikan dan sumbet protein lainnya; 3) Mengonsumsi sayuran dan cukup buah-buahan; 4) Membiasakan membawa bekal makanan dan air putih dari rumah; 5) Membatasi mengonsumsi makanan cepat saji, jajanan, dan makanan selingan yang manis, asin, dan berlemak (Hardiansyah \& Supariasa, 2014)

Pembiasaan merupakan kegiatan yang dilakukan secara berulang-ulang agar sesuatu tersebut dapat menjadi kebiasaan (Anis, 2013). Belajar kebiasaan adalah proses pembentukan kebiasaan-kebiasaan baru atau perbaikan kebiasaan-kebiasaan yang telah ada (Muhibbin, 2008). Oleh karena itu, pola makan..atau pembiasaannmakannyangNbaikNdan teraturNperlu..diperkenalkan sejak dini.

Anak prasekolah merupakan kelompok anak..yang peka terhadapNpendidikanNdanNpenanam an..kebiasaan hidup yang sehat (Santoso \& Ranti, 2009). Pendidikan dan..pembiasaan pola hidup bersih dan sehat, dan..menjaga kesehatan serta penyediaan..kebutuhan yang sesuai, khususnya melalui makanan sehari-hari bagi seorang anak sangat diperlukan untuk mencapai tigkat pertumbuhan dan..perkembangan yang optimal (Siswanto, 2010).

Cara pembiasaan mengonsumsi makanan sehat pada anak berbedabeda, hal ini dibuktikan dari hasil observasi.awal dan wawancara terhadap guru dan wali murid kelompok A yang peneliti lakukan beberapa kali selama bulan oktober 2018 di TK Gaya Baru III Surakarta mengenai pembiasaan mengonsumsi 
makanan sehat anak usia 4-5 tahun. diketahui bahwa pembiasaan anak dalam mengonsumsi makanan sehat hanya 6 anak dari 16 anak yang sudah terbiasa mengonsumsi makanan sehat. Berdasarkan paparan diatas dapat disimpulkan pembiasaan mengonsumsi makanan sehat anak kelompok A TK Gaya Baru III Surakarta tahun ajaran 2018/ 2019 masih rendah dan perlu ditingkatkan.

Kurangnya pembiasaan mengonsumsi makanan sehat dapat disebabkan oleh beberapa faktor, faktor yang terbagi atas internal dan eksternal. Faktor internal yang mempengaruhi usia anak, aktivitas anak dan kesehatan anak tersebut sedangkan faktor eksternal adalah faktor ekonomi, pendidikan dan lingkungan (Fikawati \& Syafiq, 2007).

Kegiatan..pembelajaran yang menunjang untuk membiasakan anak dalam mengonsumsi makanan sehat salah satunya dengan melalui kegiatan..cooking class. Pernyataan ini..sesuai dengan pendapat JarpeRatner (2016) yaitu program/ kegiatan cooking class dapat meningkatkan kesukaan anak pada buah-buahan dan sayur-sayuran. Cooking class..atau sering disebut kelas memasak yang memiliki manfaat belajar mengenai makanan sehat karena..pada kegiatan memasak anak akan mengerti cara memilih makanan..yang lebih sehat untuk dikonsumsi sehari-hari, pelaksanaan kegiatan cooking class dapat dilakukan selama tiga minggu untuk mendapatkan hasil yang optimal sebagai upaya pembiasaan mengonsumsi makanan sehat (Dixon, 2012 ).

Patricksia, dkk menjelaskan bahwa adanya campur tangan school based intervention yang terdiri dari school gardening, cooking class, dan..pemberian buah dan sayur mengarah pada peningkatan pengetahuan dan perilaku..mengenai konsumsi buah dan sayur. Pengamatannndinlapangan..menunjuk kan bahwa kegiatan cooking class yang kemudian dilakukan makan bersama..nnnnsetelahnnnnnkegiatan berlangsung dan pemberian buah dan sayur pada anak dapat..mempengaruhi kesukaan buah dan sayur pada anak, seperti sebagian anak tidak menyukai..makan buah nanas, 
tetapi..ketika melihat teman yang lain mengonsumsi buah nanas maka anak akan..ada rasa keinginan untuk..mengonsumsibuah nanas juga. Sikap positif pada anak juga dibuktikan dengan..partisipasi anak dalam memilih makanan yang dikonsumsinya.

Rumusan masalah dalam
penelitian ini adalah apakah
penerapan kegiatan cooking class
dapat membiasakan mengonsumsi
makanan sehat pada anak taman
kanak-kanak?

\section{Pembiasaan}

Mengonsumsi

\section{Makanan Sehat}

Pemilihan makanan..mencakup rasa suka akan suatu makanan terbentuk oleh rasa..senang atau puas yang didapatkan pada waktu mengonsumsi..makanan, sehingga akan membentuk perilaku khas yang berkaitan dengan makanan. Selain jenis makanan yang dipilih, kebiasaan terkait makanan yaitu didapat..dari hasil pengaruh lingkungan terhadap budaya.

\section{Pembiasaan merupakan} kegiatan yang dilakukan secara berulang-ulang agar sesuatu tersebut dapat menjadi kebiasaan (Anis, 2013). Kebiasaan makan..merupakan cara-cara individu atau kelompok individu dalam..memilih, mengonsumsi, dan menggunakan makanan (Santoso \& Ranti 2009). Sehubungan dengan..pendapat Santoso \& Ranti (2009) kebiasaan makan dikenal..sebagai pola makan yang ada pada seorang anak. Pola makan..mengandung berbagai informasi mengenai cara anak dalam memilih makanan..dan mengonsumsinya.

\section{Kegiatan Cooking Class}

Kegiatan cooking class memiliki pengertian yaitu jenis..intervensi yang menjanjikan yang dapat digunakan untuk mempromosikan pemilihan pilihan..makanan sehat dan perilaku untuk mencegah penyakit kronis (Apatu, 2016). Kegiatan ini anak dapat membuat makanan..dengan bahan-bahan aslinya sehingga, selesai kegiatan cooking class anak dapat megonsumsinya.

Beberapa manfaat yang dapat diambil pada kegiatan cooking class seperti anak-anak akan belajar dan mengenal bahan makanan serta 
langkah-langkah pembuatan suatu makanan, anak dapat membuat makanan..dengan bahan-bahan aslinya, sehingga jika sudah jadi makananya..dapat langsung dimakan oleh anak. Secara khusus Dixon (2012) menjelaskan bahwa kegiatan cooking class berkontribusi..pada kesadaran anak-anak untuk makan konsep sehat.

$$
\text { Anak saat diajari }
$$

untuk..merencanakan

dan menyiapkan makanan sehat dapat memengaruhi..kebiasaan..makan yang lebih sehat dan meningkatkan kepercayaan diri anak dalam menyiapkan makanan sehat sendiri. Kegiatan cooking class dapat dijadikan upaya untuk memberikan pengaruh pada pembiasaan mengonsumsi makanan sehat pada anak usia dini. Manfaat yang terdapat pada kegiatan cooking class dapat digunakan untuk membiasakan aspek pembiasaan anak yang berkaitan dengan konsumsi makanan sehat.

Tahap-tahap kegiatan cooking class yang digunakan untuk melakukan kegiatan cooking class menurut Rendulic (2010) meliputi: 1) Preparation (Persiapan), meyiapkan meja kerja anak, 2) Drawing \& Tasting (Membuat..dan mencicipi), yang meliputi meminta..anak untuk mencuci tangan dengan sabun, menjelaskan bahwa..hari ini akan belajar tentang (bahan-bahan yang ada), menuntun anak untuk mengikuti..petunjuk, meminta anak untuk mencicipi dan makan makanan buatannya, 3) Clean up (Membersihkan), mendorong..siswa untuk bertanggung jawab membersihkan meja dan..merapikan perlengkapan.

\section{METODE}

Penelitian ini merupakan jenis penelitian tindakan kelas. Penelitian ini dilakukan dengan tiga siklus yang tiap siklusnya terdiri dari tiga kali pertemuan. Setiap siklus terdiri dari perencanaan, pelaksanaan dan pengamatan, serta refleksi. Penelitian ini dilaksanakan di TK Gaya Baru III Surakarta yang berlangsung selama 9 bulan yaitu bulan September 2018 hingga bulan Mei 2019.

Subjek penelitian ini adalah anak usia 4-5 tahun. Pendekatan penelitian ini menggunakan pendekatan kualitatif. Data penelitian yang 
dikumpulkan berupa penerapan kegiatan cooking class di Taman Kanak-kanak. Sumber data primer yaitu anak, guru dan wali murid. Sumber data sekunder yaitu RPPH, catatan lapangan, bahan ajar dan skenario pembelajaran.

Teknik pengumpulan data kualitatif menggunakan teknik observasi, wawancara, dan dokumentasi. Uji validitas data kualitatif penelitian ini menggunakan triangulasi sumber dan triangulasi teknik. Analisis data menggunakan analisis interaktif yang terdiri dari 4 tahap yaitu pengumpulan data, reduksi data, penyajian data dan penarikan kesimpulan.

\section{HASIL DAN PEMBAHASAN}

Pelaksanaan

pembelajaran melalui kegiatan cooking class di TK Gaya Baru III Surakarta Tahun Ajaran 2018/ 2019 diantaranya meliputi beberapa tahapan yang mencakup:

\section{a. Tahap preparation}

Kegiatan dirancang sesuai dengan kondisi sekolah, dengan memanfaatkan ruang kelas. Kegiatan cooking class dilakukan didalam ruang kelas agar lebih kodusif. Guru merancang kegiatan yang dapat menarik perhatian anak agar terlihat menarik dan dapat dikerjakan dengan mudah oleh anak, sehingga anak tidak mudah bosan untuk melaksnakan kegiatan cooking class. Setiap pertemuan menu makanan yang dibuat dalam kegiatan cooking class dapat dibedakan antara pertemuan satu dengan lainnya. Hal ini bertujuan untuk memberikan pengetahuan yang lebih banyak mengenai berbagai macam menu makanan sehat yang dapat diketahui oelh anak.

Sebelum melakukan kegiatan cooking class, guru memakaikan topi koki kepada anak sebagai simbol bahwa anak akan memerankan profesi koki yang dapat membuat anak merasa antusias menjadi seorang koki kemudian menyiapkan tempat kerja anak terlebih dahulu dan memberi tahu menu makanan yang akan dibuat apa saja.

\section{b. Tahap drawing and tasting}

Alat dan bahan disiapkan oleh guru sebelum kegiatan dimulai. Alat dan bahan yang digunakan tergolong sangat mudah didapat dan diperoleh dengan mudah. Semua bahan makanan untuk membuat menu 
makanan sudah diolah dari rumah oleh guru sehingga anak-anak tinggal membuatnya saja.

Sebelum anak-anak memulai kegiatan cooking class anak-anak diminta untuk cuci tangan terlebih dahulu. Kemudian setelah semua anak-anak sudah cuci tangan, anakanak dipersilahkan kembali pada tempat kerja anak dan menghadap ke depan untuk mendengarkan menu makanan yang akan dibuat.

Guru menjelaskan bahwa kegiatan cooking class ini akan membuat dua menu makanan anak dijelaskan bahan-bahan yang digunakan dan menjelaskan urutanurutan cara membuat menu makanannya. Kemudian anak-anak diminta untuk memutar kursinya ke tempat kerja yang telah disediakan alat dan bahan yang digunakan untuk melaksanakan kegiatan cooking class. Setelah itu, anak-anak mulai membuat menu makanan dan juga dituntun oleh guru langkah demi langkah untuk membuat menu makanannya.

Setelah selesai membuat menu makananya anak-anak makan bersama, tetapi sebelum makan anakanak berdoa dulu bersama-sama.
Anak-anak kemudian makan bersama menu makanan yang telah dibuatnya tadi.

c. Tahap clean up

Setelah kegiatan makan bersama anak-anak membersihkan tempat kerjanya dan membereskan alat serta bahan yang digunakan. Tidak lupa membuang sampah apabila ada sampah ke tempat sampah serta cuci tangan.

Pembiasaan mengonsumsi makanan sehat melalui kegiatan cooking class pada anak kelompok A TK Gaya Baru III Surakarta mulai dari pratindakan sampai dengan siklus III mengalami peningkatan. Hal tersebut terbukti dari hasil observasi tiap siklusnya dari masing-masing indikator penilaian yaitu mengonsumsi daging dan sumber protein tertentu dengan porsi seimbang, mengonsumsi sayuran dengan porsi seimbang dan mengonsumsi buah-buahan dengan porsi seimbang yang mengalami peningkatan secara terus menerus.

Berdasarkan hasil observasi awal terhadap anak di kelompok A TK Gaya Baru III Surakarta diketahui 
bahwa pembiasaan anak dalam mengonsumsi makanan sehat hanya 6 anak dari 16 anak sudah terbiasa mengonsumsi makanan sehat sedangkan 10 anak belum terbiasa mengonsumsi makanan sehat.

Hasil observasi siklus I pada kegiatan cooking class untuk membiasakan mengonsumsi makanan sehat pada anak diketahui bahwa terdapat 1 anak belum berkembang diartikan anak hanya mau mencicipi sedikit dengan bujukan guru, terdapat 6 anak mulai berkembang diartikan anak menghabiskan seperempat porsi, terdapat 4 anak berkembang sesuai harapan diartikan anak menghabiskan setengah porsi dan terdapat 5 anak berkembang sangat baik diartikan anak menghabiskan satu porsi dalam mengonsumsi daging dan sumber protein lainnya.

Hasil observasi anak pada indikator mengonsumsi sayuran dalam porsi seimbang diketahui bahwa ada 3 anak belum berkembang diartikan anak hanya mau mencicipi sedikit dengan bujukan guru, ada 8 anak mulai berkembang diartikan anak menghabiskan seperempat porsi, ada 2 anak berkembang sesuai harapan diartikan anak menghabiskan setengah porsi serta ada 3 anak berkembang sangat baik diartikan anak menghabiskan satu porsi dalam mengonsumsi sayuran.

Hasil observasi anak pada indikator mengonsumsi buah-buahan dalam porsi seimbang diketahui bahwa 2 anak belum berkembang diartikan anak hanya mau mencicipi sedikit dengan bujukan guru, 7 anak mulai berkembang diartikan anak menghabiskan seperempat porsi, 3 anak berkembang sesuai harapan diartikan anak menghabiskan setengah porsi serta 4 anak berkembang sangat baik diartikan anak menghabiskan satu porsi dalam mengonsumsiaaaaaaaaabuah-buahan.

Hasil refleksi dari siklus I yaitu: a) anak baru pertama kali membuat menu makanan melalui kegiatan cooking class; b) anak kurang begitu mengenal menu makanan yang dibuat; c) anak baru pertama mencoba menu makanan tersebut.

Berdasarkan hasil refleksi dari siklus I tersebut maka dapat diberikan solusi berupa: a) Pemilihan bahanbahan dan menu makanan juga sangat 
berpengaruh dengan kelangsungan kegiatan cooking class; b) bahanbahan dan menu makanan yang sudah dikenal anak dapat menarik perhatian anak untuk membuat menu makanan dalam kegiatan cooking class.

Siklus II mengalami peningkatan memiliki peningkatan dalam pembiasaan mengonsumsi makanan sehat pada anak. Hasil yang diperoleh dapat meningkat, tetapi ada beberapa hal yang masih perlu diperbaiki lagi dalam pelaksanaan kegiatan pembelajaran melalui kegiatan cooking class. Hasil observasi aktivitas anak dalam pembelajaran kegiatan cooking class untuk membiasakan mengonsumsi makanan sehat anak diketahui bahwa ada 3 anak yang mulai berkembang diartikan anak menghabiskan seperempat porsi, ada 5 anak berkembang sesuai harapan diartikan anak menghabiskan setengah porsi. Anak yang berkembang sangat baik ada 8 anak diartikan anak menghabiskan satu porsi dalam mengonsumsi daging dan sumber protein lainnya.
Hasil observasi aktivitas anak pada indikator mengonsumsi sayuran dalam porsi seimbang terdapat 7 anak mulai berkembang diartikan anak menghabiskan seperempat porsi, ada 3 anak berkembang sesuai harapan diartikan anak menghabiskan setengah porsi dan 6 anak berkembang sangat baik diartikan anak menghabiskan satu porsi dalam mengonsumsi sayuran.

Hasil observasi aktivitas anak pada indikator mengonsumsi buahbuahan dalam porsi seimbang terdapat 5 anak mulai berkembang diartikan anak menghabiskan seperempat porsi, 4 anak berkembang sesuai harapan diartikan anak menghabiskan setengah porsi dan ada 7 anak yang berkembang sangat baik diartikan anak menghabiskan satu porsi dalam mengonsumsi buahbuahan.

Hasil pengamatan yang terlihat pada siklus II, pembiasaan makan anak pada saat kegiatan cooking class berlangsung sudah mengalami peningkatan, dilihat sudah tidak ada anak yang belum berkembang. Beberapa hal yang membuat anak mulai suka terhadap makanan 
bersumber protein yang dibuat antara lain: anak membuat menu makanan sendiri melalui kegiatan cooking class sehingga anak merasa antusias dalam mengonsumsi makanan hasil buatannya, anak merasa familiar dengan menu makannan yang dibuat, dan menu makanan yang dibuat bervariasi jadi anak tidak bosan.

Pada siklus III hasil observasi aktivitas anak dalam pembelajaran melalui kegiatan cooking class untuk membiasakan mengonsumsi makanan sehat pada anak diketahui bahwa ada 1 anak berkembang sesuai harapan diartikan anak menghabiskan setengah porsi dan anak yang berkembang sangat baik ada 15 anak diartikan anak menghabiskan satu porsi dalam mengonsumsi daging dan sumber protein lainnya.

Hasil observasi aktivitas anak pada indikator mengonsumsi sayuran dalam porsi seimbang terdapat 4 anak berkembang sesuai harapan diartikan anak menghabiskan setenagh porsi dan 12 anak berkembang sangat baik diartikan anak menghabiskan ssatu porsi. Hasil observasi aktivitas anak pada indikator mengonsumsi buah- buahan dalam porsi seimbang terdapat 3 anak berkembang sesuai harapan diartikan anak menghabiskan setengah porsi dan ada 13 anak yang berkembang sangat baik diartikan anak menghabiskan satu porsi.

Anak menunjukkan peningkatannya dalam mengonsumsi sumber protein, sayur dan buahbuahan setelah dilakukannya kegiatan cooking class. Peningkatan dapat dilihat ketika peneliti melakukan pengamatan pada beberapa anak yang memiliki pembiasaan mengonsumsi makanan sehat yang masih berkembang pada siklus II. Pada saat selesai kegiatan cooking class anakanak makan bersama hasil dari masakannya, kebanyakan anak mulai suka mengonsumsi sumber protein, sayur dan buah-buahan yang ada pada menu makanan yang dibuatnya. Hal ini berguna untuk membuat anak terbiasa mengonsumsi makanan sehat. pembiasaan anak dalam mengonsumsi sumber protein, sayur dan buahbuahan dapat dilihat secara nyata ketika anak makan hasil masakannya. Anak mau mengonsumsi sayur dalam menu makanannya. 
Sejalan dengan Dixon (2012) mengungkapkan bahwa kegiatan cooking class berkontribusi..pada kesadaran anak-anak untuk makan konsep sehat. Mengajari anak..untuk..merencanakan dan menyiapkan makanan sehat dapat memengaruhi..kebiasaan..makan yang lebih sehat dan meningkatkan kepercayaan diri anak dalam menyiapkan makanan sehat sendiri. Menyediakannpanduan..pendamping.. bag orang tua untuk mendukung perencanaan menu anak-anak di..rumah dapat memajukan upaya ini lebih lanjut. Kunci..untuk kebiasaan makan yang lebih sehat bisa jadi perencanaan sebelum makan. Kegiatan cooking class menjadi salah satu cara cukup optimal untuk membiasakan mengonsumsi makanan sehat. Pada siklus I sampai siklus III mengalami peningkatan secara signifikan pada seluruh indikator pembiasaan mengonsumsi makanan sehat pada anak.

\section{SIMPULAN}

Berdasarkan hasil penelitian
tindakan kelas yang telah
dilaksanakan dalam tiga siklus

dengan menerapkan kegiatan pembelajaran melalui kegiatan cooking class untuk membiasakan mengonsumsi makanan sehat pada anak kelompok A TK Gaya Baru III Surakarta, dapat disimpulkan bahwa melalui kegiatan cooking class dapat membiasakan mengonsumsi makanan sehat pada anak kelompok A TK Gaya Baru III Surakarta Tahun Ajaran 2018/ 2019.

Terbiasanya mengonsumsi makanan sehat pada anak dibuktikan dengan meningkatnya kebiasaan anak dalam mengonsumsi makanan sehat. Kebiasanaan tersebut dapat dilihat dari rata-rata anak yang kurang suka mengonsumsi daging dan sumber protein lainnya, mengonsumsi sayuran dan mengonsumsi buahbuahan yang terdapat pada menu makanan. Anak menghabiskan makanan bersumber protein, sayur dan buah-buahan dalam menu makanan. Pembiasaan terhadap mengonsumsi makanan sehat anak juga meningkat yaitu anak dapat melakukan pembiasaan membawa bekal makanan dari rumah sendiri setiap harinya. 
Sesuai dengan simpulan hasil penelitian, maka ada beberapa saran yang dapat dipergunakan sebagai nahan pertimbangan untuk membiasakan mengonsumsi makanan sehat pada anak kelompok A TK Gaya Baru III Surakarta sebagai berikut:

\section{Bagi anak}

Anak dapat berpartisipasi aktif dalam pelaksanaan kegiatan coooking class mulai dari tahap preparation sampai tahap clean up. Hal tersebut dapat dijadikan bahan masukan agar anak dapat terlibat langsung seluruh kegiatan cooking class. Sehingga pembelajaran dapat berjalan lancar menjadi bermakna dan memperoleh hasil yang maksimal mengingat pentingnya pembiasaan mengonsumsi makanan sehat pada anak.

2. Bagi guru

a. Guru dapat mengembangkan kegiatan cooking class sesuai dengan kreativitas masingmasing agar anak tidak merasa jenuh terhadap kegiatan pembelajaran yang digunakan.

b. Pengkondisian sebelum memulai pembelajaran dapat dilaksanakan dengan ice breaking agar anak lebih fokus dan semangat

3. Bagi sekolah

a. Sekolah hendaknya dapat memberikan fasilitas yang dibutuhkan guru untuk melaksanakan kegiatan cooking class sehingga guru tidak kesulitan dalam menyiapkan bahan dan materi ajar

b. Sekolah dapat memerikan perhatian guru dalam memperkaya kegiatan pembelajaran untuk membiasakan mengonsumsi makanan sehat pada anak

4. Bagi orang tua

Orang tua dapat lebih mengetahui menu makananmakanan sehat yang dibutuhkan oleh anak supaya dapat membiasakan anak mengonsumsi makanan sehat disekolah maupun dirumah.

5. Bagi peneliti selanjutnya 
Keterbatasan tempat membuat suasana kurang kondusif menyebabkan penelitian ini kurang mendalami materi makanan sehat yang akan disampaikan sebelum kegiatan cooking class. Peneliti selanjutnya yang ingin melanjutkan hendaknya dapat membuat suasana kondusif walaupun keterbatasan tempat

\section{DAFTAR PUSTAKA}

Anis, I. M., dkk. (2013). Pendidikan nasionalisme melalui pembiasaan di SD Negeri Kuningan $02 \quad$ Semarang Utara. Jurnal: UNES.

Apatu, E. (2016). Cooking classes: are they effective nutrition interventions in low-income settings?.Journal of Nutrition Education and Behavior, Vol 48 No $7 \mathrm{~S}$.

Patricksia, D. D., dkk (2018). School based intervention sebagai upaya perbaikan konsumsi buah dan sayur siswa sekolah dasar. Jurnal MLKMI, Vol 15 No. 3

Dixon, E. (2012). Cooking and menu planning confidence of children participating in a cooking camp. Thesis. Chemson University.

Fikawati, R. \& Syafiq. (2007). Gizi dan kesehatan masyarakat. Fakultas kesehatan masyarakat universitas indonesia, Jakarta: 253-263.

Hardiansyah \& Supariasa D. N. (2014). Ilmu gizi teori \& aplikasi. Jakata: EGD.

Jarpe-Ratner，E. Dkk. (2016). An experiential cooking and nutrition education program increases cooking selfefficacy and vegetable consumtion in children in grades 3-8. Journal of Nutrition Education and Behavior.

Muhibbin. S. (2008). Psikologi pendidikan dengan pendekatan baru. Bandung: PT Remaja Rosdakarya. 
Rendulic, S. H. (2010). Let's cook! Class curriculum. Washington State Department of Health. E-Book.

Santoso, S. \& Ranti A. L. (2009). Kesehatan dan gizi. Jakarta: Rineka Cipta.

Siswanto, H. (2010). Pendidikan kesehatan anak usia dini. Yogyakarta: Pustaka Rihan 
KUMARA CENDEKIA Vol. 7 No. 3 September 2019 